\title{
ANALISIS ANTROPOLOGI HUKUM TERHADAP PERDAGANGAN LINTAS BATAS DI KALIMANTAN BARAT (UPAYA PENCARIAN MODEL DAN POLA PERLINDUNGAN HUKUM)*
}

\author{
Hermansyah \\ Fakultas Hukum Universitas Tanjungpura Pontianak \\ E-mail: hermansyah_fh@yahoo.com
}

\begin{abstract}
Abstrack
Due to its geographic location bordering directly with neighboring countries, the border in West Kalimantan as the outer limit of the state of Indonesia is one region that has not received attention, especially attention with regard to activities in the economic field. Cross Border Trade and Market in the Border area, for example, is so much economic activity along the border there is a transaction involving the people who come from two different countries and have different legal systems. In the perspective of legal anthropology, it is probably legal system that applies to communities in the border area showed such legal pluralism, if not addressed carefully, it did not rule out the trade problems that occur in communities in the border area will be sticking to the issue between countries, because of differences in existing law. Therefore, efforts to create a model that would be able to accommodate the parties-such as community, nation and state of Indonesia-Malaysia would need to be pursued, so the problem is not a legal issue to drag on the interests of each party.
\end{abstract}

Key words: Cross Border Trade, legal systems and legal pluralism.

\begin{abstract}
Abstrak
Karena kondisi geografis yang berbatasan secara langsung dengan Negara tetangga, maka Kalimantan Barat merupakan salah satu wilayah Negara Indonesia yang berbatasan secara langsung dengan Negara tetangga yang belum mendapatkan perhatian terutama berkenaan dengan aktivitas perdagangan yang sudah berlangsung sejak lama. Perdagangan di daerah perbatasan merupakan perdagangan yang melibatkan dua warga Negara yang berbeda, terutama perbedaan sistem hukum yang ada. Dalam perspektif antropologi hukum, aturan yang ada dalam perdagangan di daerah perbatasan memperlihatkan pluralitas hukum. Oleh karena itu, perlu dicarikan sebuah model aturan yang mampu memberikan kepastian semua pihak jika terjadi sengketa dagang di pasar perbatasan.
\end{abstract}

Kata Kunci: perdagangan daerah perbatasan, sistem hukum dan pluralisme hukum

\section{Pendahuluan}

Negara Kesatuan Republik Indonesia dengan luas wilayah sekitar $5.800 .000 \mathrm{~km}^{2}$ berada pada posisi yang sangat strategis di antara negara-negara di dunia, karena berada pada posisi silang di antara pertengahan jalur perdagangan dunia. Namun posisi yang strategis itu diperkirakan dapat menimbulkan berbagai permasalahan, apalagi mengingat semakin ter-

* Tulisan ini merupakan hasil penelitian Hibah Kompetensi Direktorat Jenderal Pendidikan Tinggi Kementerian Pendidikan Nasional Sesuai Dengan Surat Perjanjian Penugasan Hibah Kompetensi Nomor: 391/ SP2H/PP/ DP2M/ VI/ 2010 tanggal 11 juni 2010. batasnya sumber daya alam, perkembangan dan pertumbuhan ekonomi global dan regional. Permasalahan akan semakin kompleks mengingat bahwa berdasarkan data Kementerian Negara Pembangunan Daerah Tertinggal 2005 menunjukkan bahwa sebagian besar Kabupatenkabupaten di wilayah perbatasan tergolong wilayah tertinggal. Padahal kabupaten di wilayah perbatasan, termasuk pulau-pulau kecil di perbatasan, memiliki peran yang menentukan 
sebagai garda terdepan perekonomian bangsa Indonesia. ${ }^{1}$

Kondisi tersebut di atas kiranya yang menyebabkan berbagai persoalan, terutama kejahatan yang terjadi di daerah perbatasan seperti penebangan kayu secara ilegal (illegal logging), pencurian ikan (illegal fishing), perdagangan wanita dan anak (women and child tratdes), dan pemasukan imigran gelap (illegal immigrants) atau illegal traffikcing in persons, dan penyelundupan baik manusia maupun barang (people, arms and explosives smuggling), serta berbagai konflik sosial dan politik yang terjadi di wilayah-wilayah perbatasan, dan lain sebagainya. Di mana kesemua persoalan tersebut pada akhirnya bisa berdampak keamanan dan ketertiban negara, terutama keamanan dan ketertiban warga masyarakat yang tinggal di wilayah perbatasan. $^{2}$

Di samping aktivitas yang sifatnya illegal, sesungguh di daerah perbatasan ada suatu aktivitas yang bernilai positif dan sudah lama dilakukan oleh masyarakat kedua negara yaitu aktivitas perdagangan, dimana pada awalnya aktivitas tersebut mereka lakukan sebagai bagian dari upaya mereka memenuhi kebutuhan hidup sehari-hari. Seperti sayur-sayuran, hasil alam seperti buah-buah dan lain sebagainya. Namun sehubungan dengan perkembangan zaman, maka produk yang diperjualbelikan tidak lagi beruapa sayuran, atau hasil alam sematamata, tetapi sudah mengarah kepada berbagai macam produk yang merupakan hasil tehnologi pada masing-masing negara. Mulai dari dari pakaian, pangan sampai pada hasil kerajinan rakyat diperjual belikan disana.

Sirikin, Lubuk Antu atau Sajingan adalah sekian banyak daerah perbatasan Kalimantan Barat dengan Malaysia yang memperlihatkan aktivitas perdagangan sebagaimana yang di-

Mustafa Abubakar, 2006, Menata Pulau-pulau Kecil Perbatasan: Belajar dari Kasus Sipadan, Ligitan dan Sebatik, J akarta: Penerbit Buku Kompas, hlm. viii

2 Poltak Partigo Nainggolan, "Masalah-masalah Keamanan di Perbatasan Indonesia dengan Negara-negara lain: Perspektif Tradisional dan Non-tradisional", dalam Nainggolan, Poltak Partigo (Ed.), 2004, Batas-batas Wilayah dan Situasi Perbatasan di Indonesia: Ancaman terhadap Integritas Teritorial, J akarta: Tiga Putra Utama, 2004. hlm. 155-156 maksud di atas. Bahkan masyarakat di daerah tersebut melakukan hubungan hukum tidak hanya dalam bentuk perdagangan saja, tetapi juga dalam bentuk lain seperti perkawinan.

Belajar dari pengalaman dan kenyataan bahwa banyaknya barang-barang yang merupakan produk bangsa indonesia yang diakui hak patennya oleh Negara tentangga (terutama Malaysia), maka adalah tepat jika perdagangan yang dilakukan oleh masyarakat Indonesia di daerah perbatasan tersebut diatur sedemikian rupa sehingga akan tercipta perlindungan hukum, baik terhadap masyarakat Indonesia sendiri berserta berbagai produk yang diperjualbelikan tersebut. Bahkan perlindungan hukum yang kiranya penting juga adalah bagaimana memberikan perlindungan hukum jika dalam aktivitas perdagangan yang dilakukan tersebut dikemudian hari timbul permasalah seperti wanprestasi atau diklaimnya produk kerajinan indonesia oleh negara tetangga. Pengabaian akan pemberian perlindungan hukum inilah yang kiranya merupakan salah satu penyebab sehingga banyaknya produk yang dihasilkan oleh bangsa Indonesia diakui dan dipatenkan oleh negara tetangga.

Dari pra penelitian yang dilakukan, kiranya selama ini belum ada satu model dan pola perlindungan hukum yang diberikan oleh negara kepada masyarakat yang melakukan aktivitas perdagangan di perbatasan kedua negara, terutama dalam hal ini perlindungan hukum dari negara. Memang selama ini masyarakat dikedua perbatasan tersebut telah mengembangkan sistem dan model perlindungan hukum sendiri yang mereka lakukan secara turun temurun, seperti pola dan model negosiasi.

\section{Permasalahan}

Mendasarkan pada paparan tersebut di atas, secara umum permasalahan dalam tulisan ini adalah bagaimana perlindungan hukum terhadap aktivitas perdagangan yang ada di daerah perbatasan. Permasalahan ini menjadi penting mengingat belum adanya satu bentuk perlindungan hukum yang diberikan terhadap para pelaku perdagangan yang ada di daerah perbatasan yang keberadaannya sudah lama 
dilakukan oleh masyarakat yang ada di daerah perbatasan tersebut, sementara jika dilihat dari subyek hukum yang ada pada pasar perbatasan adalah subyek hukum yang berasal dari dua negara yang bertentangga (Malaysia dan Kalimantan Barat) yang memiliki sistem dan budaya hukum yang berbeda satu dengan yang lainnya serta banyaknya permasalahan hukum yang muncul dalam aktivitas perdagangan perbatasan tersebut.

\section{Metode Penelitian}

Riset tentang aktivitas perdagangan lintas batas di wilayah perbatasan Kalimantan Barat (Indonesia) dengan Malaysia dengan Malaysia Utara, terutama di tiga titik daerah perbatasan yaitu daerah Sirikin (Kabupaten Bengkayang), Lubuk Antu (Kabupaten Kapuas Hulu) dan Sajingan (Kabupaten Sambas) menggunakan paradigma konstruktivisme, dengan menggunakan berbagai macam pendekatan seperti pendekatan kualitatif, dialietikal, analisis kasus, ${ }^{3}$ dan pendekatan budaya.

Teknik penentuan dan pengambilan sumber informasi menggunakan teknik snow ball (bola salju). Melalui 'semi-structured interview', peneliti berpedomankan pada daftar pertanyaan yang disusun secara terbuka sehingga memberikan kesempatan untuk probing atau melakukan penyelidikan/pemeriksaan lebih jauh. Penggunaan teknik probing ini di maksudkan agar narasumber (informan) memiliki kesempatan untuk mengemukakan pendapatnya tentang apa yang dilihat, dengar, lakukan atau baca tentang informasi yang berkaitan dengan masalah aktivitas legal perbatasan yang menjadi obyek utama riset ini.

Guna diperolehnya data yang memiliki validitas (kesahihan) yang dapat dipertanggungjawabkan, maka data yang diperoleh melalui wawancara dilakukan uji mutu data. Dan salah

\footnotetext{
Lihat penjelasan tentang pendekatan ini dalam Indarti, Erlyn. "Legal Constructivism: Paradigma Baru Pendidikan Dalam Rangka Pembangunan Masyarakat Madani", dalam Majalah IImiah Masalah-Masalah Hukum, Vol. XXX, No. 3, Juli - September 2001, hlm. 139-154 dan Suparlan, Parsudi, "Paradigma Naturalistik dalam Penelitian Pendidikan: Pendekatan Kualitatif dan Penggunaannya", Majalah Antropologi Indonesia No. 53, Vol. 21 1997, diterbitka oleh FISIP UI J akarta.
}

satu tehnik untuk melakukan uji mutu data dengan tinggal bersama dengan orang-orang yang diteliti selama suatu periode tertentu. Selain validitas data, maka hal yang terpenting juga data tersebut harus memiliki sifat reliabilitas (keterandalan), kemudian data tersebut akan di komfirmasi ulang kepada sumber informasi.

\section{Pembahasan \\ Pasar di daerah Perbatasan: Beberapa Pe- maknaan}

Secara geografis Negara Indonesia merupakan salah satu negara kepulauan yang berbatasan langsung dengan negara tetangga. Kondisi geografis seperti ini bisa menimbulkan berbagai persoalan bagi dua negara yang saling berbatasan, baik persoalan dalam bidang geografis seperti masalah tapal batas antar kedua negara, maupun persoalan kondisi sosial, ekonomi, politik dan dan bahkan persoalan budaya. Apalagi antara kedua Negara memperlihatkan kondisi yang berbeda secara tajam.

Namun demikian, di samping berbagai persoalan seperti tersebut di atas, kiranya wilayah perbatasan, juga memiliki berbagai macam potensi yang cukup besar bagi suatu Negara, mulai potensi sumber daya alam yang dimiliki, serta dapat dijadikan tempat yang relatif mudah dalam mengatur hubungan sosial dan ekonomi antara antara kedua negara yang saling bertetangga. Bahkan karena berbatasan secara langsung dengan Negara tetangga kiranya daerah perbatasan merupakan daerah yang sangat strategis dari sisi ideologi, politik ekonomi, sosial budaya, dan pertahanan dan keamanan. Namun demikian dalam kenyataannya posisi yang strategis tersebut karena tidak di kelola dengan baik maka justru yang muncul adalah berbagai persoalan sosial, ekonomi dan budaya yang mengedepan.

Kabupaten sambas (Sajingan), Kabupaten Bengkayang (Sirikin) dan Kabupaten Kapuas HuIu (Lubuk Antu) adalah tiga wilayah yang letak geografisnya secara langsung berbatasan dengan negara tetangga. Di tiga daerah yang berbatasan langsung dengan Malaysia tersebut terdapat pasar. Sebagai tempat pertemuan manu- 
sia dengan segala macam keunikan yang ada padanya, menjadikan pemaknaan terhadap pasar memperlihatkan keberagaman. Dalam maknanya yang awal misalnya, pasar merupakan tempat pemenuhan kebutuhan pokok manusia, meskipun tidak selama terpenuhi. ${ }^{4}$

Keberadaan pasar yang ada di perbatasan sebagai tempat jual beli barang antara pedagang Kalbar dan Sarawak (Malaysia) yang sudah berlangsung cukup lama, yang pelaksanaan transaksinya terjadi pada hari-hari tertentu yaitu pada hari sabtu dan minggu. ${ }^{5}$ Aktivitas pada hari-hari tertentu ini memperlihatkan bahwa pasar yang ada di daerah perbatasan masih dalam bentuk yang sederhana. ${ }^{6}$

Pada sisi lain, keberadaan pasar juga dinilai oleh masyarakat merupakan salah satu solusi terhadap persoalan kerja, pasar dinilai mampu menawarkan kesempatan kerja yang

Lebih jauh lihat Walter $\mathrm{C}$. Naele, "The Market in Theory and History" dalam Karl Polonyi et.al. (ed), 1971, Trade and Market in The Early Empires: Economics in Theory And History, Chicago Henry Regnery Company, $\mathrm{hlm}$. 360-365. Lihat dan bandingkan dengan A. Stoler, "Garden Use and Hosehold Economy in Rural Java", Bulletin of Indonesian Economic Studies XIV (2), 1981; dan Adri Poesoro, "Pasar Tradisional Di Era Persaingan Global", Newsletter SMERU, Lembaga Penelitian SMERU No. 22, April-J uni 2007.

5 Berdasarkan hasil penelitian yang dilakukan terhadap pasar yang ada di daerah perbatasan, bahwa kegiatan pasar tidak dilaksanakan pada setiap harinya tetapi hanya pada hari-hari tertentu. Di daerah Sirikin, Sajingan dan Badau misalnya, pasar ini pada umumnya hanya melaksanakan aktivitasnya selama tiga (3) hari dalam satu minggunya, yaitu pada hari Jum'at, Sabtu dan Minggu. Memang di hari-hari lain ada juga yang melakukan kegiatan di pasar tersebut, tetapi intensitas dan volume perdagangannya tidaklah seramai dan sebanyak pada hari-hari tersebut. Mengapa pada harihari tersebut-jum'at, sabtu dan minggu-merupakan hari yang ramai dalam melakukan transaksi di pasar yang ada di daerah perbatasan tersebut, hal ini berkenaan dengan banyaknya orang yang berasal dari negara tetangga yaitu Malaysia, datang pada hari tersebut untuk melakukan transaksi di pasar tersebut. Lebih jauh tentang pasar kota dan pasar desa ini lihat M. Dien Majid, 1988, "Pasar Angkup (Studi Kasus Perilaku Pasar)", dalam Perdagangan, Pengusaha Cina, Perilaku Pasar (Pengantar Dr. Dorodjatun KuntjoroJakti). Jakarta : PT. Pustaka Grafika Kita, hlm.289. Lihat dan bandingkan pula dengan Sumintarsih, 2007, "Perilaku Ekonomi Penduduk di Daerah Perbatasan Pacitan - Wonogiri", J urnal Patrawidya, Vol. VIII. No. 3, September 2007.

6 Lihat dalam Titi Surti Nastiti, 2003, Pasar di Jawa Masa Mataram Kuna Abad VIII-IX Masehi, J akarta: PT. Dunia Pustaka Jaya, hlm. 140. Lihat juga F. A. Sutjipto, "Beberapa Tjatatan Singkat Tentang Pasar-Pasar Di Djawa Tengah (Abad 17-18)", Buletin Fakultas Sastra dan Kebudayaan, No. 3, Tahun 1970. cukup lebar dan menjadi "jawaban spontan (yang) penuh prakarsa dari rakyat terhadap negara yang dinilai belum mampu memenuhi kebutuhan pokok golongan penduduk yang ada di sekitar perbatasan", di samping sebagai tempat untuk mengalirkan dan menyalurkan kelebihan barang yang diproduksi untuk dijual. ${ }^{7}$

Di samping pemaknaan tersebut di atas, kiranya pasar dapat juga dilihat dalam perspektif antropologi, ${ }^{8}$ yang tidak hanya memperhatikan keberadaan masyarakat yang masih sederhana, tetapi juga memperhatikan interaksi dan dinamika masyarakat moderen.

Seperti yang telah diuraikan di atas bahwa sesunggunya masyarakat yang tinggal di daerah perbatasan pada umumnya mereka mempunyai hubungan kekeluargaan dengan penduduk dari negara tetangga, baik karena perkawinan ataupun memang karena sejak awalnya mereka berasal dari satu keturunan. ${ }^{9}$ Hubungan yang erat ini juga tentunya berpengaruh pada bentuk dan sifat relasi sosial antar etnik yang ada di daerah perbatasan, juga tentunya pola hubungan ekonomi antara keduanya. Hanya karena batas dan teritorial negara sajalah yang memisahkan mereka. Kondisi inilah yang kiranya transaksi diantara mereka mengenal sistem barter. Sistem barter ini biasanya dilakukan oleh penduduk asli yang berasal dari Kalimantan Barat dengan penduduk Malaysia yang ada di sekitar masyarakat perbatasan, terutama yang dijadikan obyek untuk

Titi Surti Nastiti, op.cit, hlm. 21.

8 Lebih diskursus tentang pengertian antropologi dalam S. Budhisantoso, 1992/1993, "Pembinaan dan Pengembangan Kebudayaan Nasional", J urnal Kebudayaan No. 4 Tahun II 1992/1993, Jakarta: Departemen Pendidikan dan Kebudayaan.

9 Dari beberapa penelitian yang dilakukan sebelumnya terlihat bahwa suku yang mendiami sepanjang daerah perbatasan Kalimantan Barat pada umumnya adalah suku dayak Iban. Di Badau misalnya, suku dayak iban yang ada di sana pada umumnya adalah pendatang dari Batang Aek Sarawak Malaysia yang meurpakan kawasan sempadan (termasuk Nanga Badau ) dan basis persebaran suku Iban, dan dahulunya merupakan wilayah pembunuhan atau pengayauan yang disebut oleh para pengkaj i dari barat sebagai "pintu bunoh" atau the door of killing, "pintu kayau" atau the door of raiding. Lebih jauh lihat Sandin, B. "The Westward Migration of the Sea Dayaks", dalam The Sarawak Museum J ournal Vol VII, 1956. Kuching, Museum Sarawak. Ibrahim MS., "Orang Iban di Badau", dalam Yusriadi, Chong Sin dan Dedy Ari Aspar (Eds), 2007, Kelompok Ibanik di Kalimantan Barat, Pontianak: STAIN Pontianak Press. 
barter adalah barang hasil pertaniannya dari kedua penduduk. Dan barter ini hanya berlaku pada masyarakat yang ada di sekitar perbatasan tersebut yang memiliki hubungan kekeluargaan satu dengan yang lainnya, baik hubungan karena garis keturunan maupun karena perkawinan. ${ }^{10}$

Pada sisi inilah sesungguhnya dapat dilihat bahwa barter ataupun jual beli yang terjadi sesungguhnya bukan semata-mata dilihat sebagai aktivitas ekonomi semata, tetapi juga memiliki makna berupa pertemuan diantara mereka yang memiliki hubungan kekeluargaan. Dalam pertemuan inilah akan terjadi pertukaran informasi tentang keadaan keluarga mereka masing-masing.

Manusia tidak terlepas dari kebudayaannya, dimana kebudayaan yang dipunyai oleh manusia merupakan jembatan antara hubungan kegiatan manusia dengan lingkungannya. Kebudayaan merupakan alat kontrol bagi kelakuan dan tindakan manusia. Menurut Koentjaraningrat $^{11}$ kebudayaan itu sendiri mempunyai tiga wujud: pertama, kebudayaan sebagai suatu kompleks dari ide-ide, gagasan, nilai-nilai, norma-norma, peraturan dan sebagainya. Kedua, kebudayaan sebagai suatu kompleks aktivitas kelakuan berpola dari manusia dalam masya-

10 Pasar yang ada di daerah perbatasan tidaklah selalu dalam bentuk transaksi jual beli antara pedagang dengan pembeli, tetapi juga ada aktivitas tukar menukar barang atau yang dikenal dengan istilah barter. Sistem barter ini biasanya dilakukan oleh penduduk asli yang berasal dari Kalimantan Barat dengan penduduk Malaysia yang ada di sekitar masyarakat perbatasan, terutama yang dijadikan obyek untuk barter adalah barang hasil pertaniannya dari kedua penduduk. Dan barter ini hanya berlaku pada masyarakat yang ada di sekitar perbatasan tersebut yang memiliki hubungan kekeluargaan satu dengan yang lainnya, baik hubungan karena garis keturunan maupun karena perkawinan. Lihat dan bandingkan dengan tulisan Wilson, "Adaptation to Uncertainty and Small Number Exchange: The New Sugland Fish Market", J ournal of Economic 11, 1980. Lihat dan bandingkan dengan M. Firdaus, "The Integrated Empowerment of Women, Micro-and SmallScale Traders", Newsletter SMERU, Lembaga Penelitian SMERU No. 22, April-J uni 2007.

11 Koentjaraningrat, 1971, Manusia dan Kebudayaan di Indonesia, J akarta: Penerbit Djambatan, hm.l 5. Lihat dan bandingkan rangkaian pengertian kebudayaan ini dalam Hutomo, Suripan Sadi, "Nilai Budaya Indonesia Dalam Sastra Jawa", J urnal Kebudayaan No. 2, 1991/ 1992, J akarta: Dep. Pendikan dan Kebudayaan rakat. Wujud kebudayaan yang ketiga adalah sebagai benda-benda hasil karya manusia.

Di pasar juga akan dengan mudah orang akan melihat terjadi perubahan nilai, gagasan, norma, kepercayaan dan aktivitas berpola dari manusia dalam masyarakat. Pasar memiliki multi peran, yaitu tidak hanya berperan sebagai tempat bertemunya antara penjual dan pembeli tetapi pasar juga memiliki fungsi sebagai tempat bertemunya budaya yang dibawa oleh setiap mereka yang memanfaatkan pasar. Interaksi tersebut tanpa mereka sadari telah terjadi pengaruh mempengaruhi budaya masing-masing individu. ${ }^{12}$

Pasar juga dapat dilihat sebagai tempat dimana aktivitas dan komunikasi sosial antara satu orang dengan orang yang lain, degan tentunya dari latar belakang sosial, budaya yang berbeda. Memang ciri khas pasar yang paling menonjol adalah adanya arus barang dan jasa yang diperjualbelikan. Namun demikian, pasar juga dapat dilihat sebagai sistem sosial kebudayaan. Bahkan pasar di dalamnya menawarkan alternatif-alternatif kebudayaan yang berlainan dari kebudayaan masyarakat setempat, sedangkan kebudayaan itu adalah seperangkat nilai-nilai dan keyakinan, pilihan hidup dan alat komunikasi. ${ }^{13}$

Pasar sebagai pintu gerbang diperkirakan akan terjadi perubahan nilai, gagasan, dan keyakinan. Pasar dapat pula diartikan sebagai sentral dari masyarakat yang berada disekitarnya. Pasar di dalamnya bukan saja akan terjadi saling interaksi sesama warga masyarakat yang ada disekitar tempat tersebut, tetapi akan terjadi pula tukar-menukar benda hasil produksi bahkan informasi-informasi tentang berbagai pengalaman diantara sesama warga masyarakat. Pasar sebagai sentral dengan segala perangkat yang ada di dalamnya dapat pula menjadi panutan masyarakat. Hal ini menunjukkan bahwa bukan hanya peranan

12 Titi Surti Nastiti, op.cit. Lihat tentang interaksi di pasar ini pada Prattis, J.I., "Synthesis, or a New Problematic in Economic Anthro-pology", Journal of Theory and Society, Vol. 11, 1982.

13 Sri-Edi Swasono, "Kebudayaan dan Ekonomi: Kedaulatan Rakyat, Demokrasi Ekonomi dan Kepentingan Nasional (Pendekatan Normatif)", J urnal Kebudayaan No. 4 Tahun II 1992/ 1993 
ekonomi, tetapi peranan kebudayaan terhadap masyarakat disekitarnya cukup besar. Perananperanan tersebut dengan demikian akan menimbulkan perubahan-perubahan baik dalam bidang ekonomi maupun sosial budaya. Bahkan pasar mampu menciptakan dan menumbuhkan kelas-kelas baru dalam masyarakat, hal ini dikarenakan pasar memiliki kemampuan dan kekuatan yang revolusioner dan proses pemasaran masyarakat yang mempunyai akibat yang jauh bagi perkembangan sejarah. Pasar menuntut perilaku rasional dalam menentukan pilihan-pilihan. ${ }^{14}$

Demikianlah misalnya di pasar yang ada di perbatasan, karena perkembangannya maka orang yang berjualan di sana saat ini bukan hanya orang-orang yang berasal dari masyarakat sekitar yang tinggal di daerah perbatasan, tetapi mereka-mereka berasal dari luar daerah tersebut. Bahkan dari penelitian yang dilakukan etnis yang berdagang disana sudah memperlihatkan pluralitas etnis di dalamnya. Mulai dari orang Padang, Melayu, bahkan orang yang berasal dari Nusa Tenggara Barat (NTB) juga ada berjualan dan berdagang di sana.

Dari segi bahasa misalnya, orang yang berada di pasar pada umumnya menggunakan bahasa yang campuran, artinya tidak sematamata menggunakan bahasa Indonesia saja, tetapi terkadang menggunakan bahasa Inggris atau bahasa Malaysia. Hal ini dilakukan oleh masyarakat sebagai bagian dari upaya agar mempermudah komunikasi antara pedangang yang pada umumnya berasal dari Indonesia dengan pembeli yang pada umumnya berasal dari Malaysia. Pola percakapan yang campuran ini tidak hanya terjadi pada saat transaksi perdagangan dilakukan, tetapi juga terbawa pada saat mereka melakukan komunikasi sesama pedagang, artinya telah terjadi bentuk pertukaran dan percampuran budaya-terutama dari sisi bahasa-antara budaya Malaysia dan Indonesia.

\footnotetext{
14 Lihat dan bandingkan dengan Plattner, "Economic Decision Making in a Public Market-place", American Ethnologist 9, 1982; Merrit, "On Questions Following Questions", Language in Society 5, 1978, hlm. 315-357.
}

\section{Pasar dan Persoalan (Pluralisme) Hukum}

Di samping memilik potensi ekonomi yang sangat besar, aktivitas perdagangan yang ada di daerah perbatasan kiranya menyimpan banyak persoalan, mulai dari persoalan keamanan dan pertahanan, sampai masalah ketahanan sosial, budaya dan ekonomi suatu Negara. Menurut Ganjar Nugroho, dalam perspektif sosialis, pasar dapat menjadi tempat dan pencitpa serta pelanggeng kemiskinan. Hal ini terjadi, karena dipasar akan terbangun kekayaan yang mencolok bagi sebagian kelas dan kemiskinan bagi sebagian yang lain. Pedagang serta pengusaha dipandang hanya memikirkan kepentingan akumulasi ekonomi untuk dirinya sendiri. Mereka tidak punya moral ekonomi sosial dan tak banyak peduli dengan nasib kaum miskin serta kelas pekerja. Pasar juga dinilai pilih kasih, yang hanya diperuntukan bagi yang punya uang untuk membeli dan menelantarkan kaum miskin yang berpenghasilan rendah tanpa konsumsi nan mencukupi. ${ }^{15}$

Kondisi ini bisa dilihat di pasar yang ada di perbatasan, dimana mereka yang berjualan di pasar tersebut pada umumnya adalah mereka yang bukan berasal dari masyarakat setempat tetapi berasal dari daerah luar seperti orang-orang yang berasal dari Pontianak serta daerah lainnya, maka mendasarkan pada struktur berpikir Ganjar Nugroho tersebut di atas maka sesungguhnya yang memperoleh keuntungan ekonomi yang cukup besar bukan masyarakat asli (suku Dayak) yang ada di sepanjang perbatasan tersebut, tetapi mereka yang berasal dari luar. Pada hal pada satu sisi barang yang menjadi salah satu komoditi utama yang ada di pasar perbatasan tersebut adalah berbagai hasil karya dari masyarakat Dayak seperti

15 Lihat Ganjar Nugroho, Dominasi-Habitasi Pasar Dan Integrasi-Resistensi Structural Wong Cilik, dalam Makalah Workshop Asian Studying Cultural in Asian Context, Kunci Cultural Studies Center, Yogyakarta, 16-17 Mei 2002. Bandingkan dengan Sri Budiyati," Pasar Tradisional Dengan Struktur Bangunan Bertingkat: Siapa yang Diuntungkan", Newsletter SMERU, Lembaga Penelitian SMERU No. 22, April-J uni 2007 dan Sri Budiyati, "Quo Vadis Pasar Tradisional", Newsletter SMERU, Lembaga Penelitian SMERU No. 22, April-J uni 2007. Dalam konteks hukum, lihat Marc Galanter, "Why the "Haves" Come Out Ahead: Speculations on the Limits of Legal Change", Law and Society Review Vol. 9, 1974. 
Biday ${ }^{16}$ dan lain sebagainya, di samping tentunya berbagai macam hasil alam dan hasil hutan yang ada disekitar daerah perbatasan seperti rotan, durian dan lain sebagainya.

Berkenaan dengan penelitian ini, yang tidak kalah pentingnya persoalan yang ada di pasar perbatasan adalah persoalan hukum yaitu diantaranya yaitu tidak adanya perlindungan hukum terhadap karya para penduduk asli (Dayak) seperti biday, serta banyaknya penyelundupan barang yang seharusnya dilindungi dengan dokumen dalam aktivitas perdagangannya.

Biday misalnya, sebagai hasil karya asli masyarakat Dayak, ternyata telah beredar dan tertera Made in Kuching (Sarawak, Malaysia Timur), bahkan menurut camat Jagoi Babang hasil kerajinan Biday dari Masyarakat Desa Jagoi Kecamatan Jagoi Babang Kabupaten Bengkayang sudah beredar di luar negeri seperti "Di London biday ini Made in Kuching," dan hal ini terjadi karena menurut Kades Jagoi Markus Mijem mereka (Malaysia) dengan mudah membeli dan mengolah kembali dari masyarakat kita. ${ }^{17}$

Sebenarnya Pemerintah Kabupaten Bengkayang pernah menegaskan, agar Pemerintah Provinsi Kalbar dan Pemerintah Pusat segera bertindak untuk menyelamatkan Kerajinan Biday dari klaim Malaysia. "Menurut saya di dunia ini, saya hanya pernah melihat Kerajnan Biday itu hanya ada di Seluas, Jagoi dan Siding. Ini adalah aset daerah kita yang dimiliki oleh negara, "18

Masyarakat Dayak pada umumnya menjual biday masih dalam bentuk sederhana, apa adanya dan belum mendapatkan sentuhan teknologi. Kondisi itu ternyata menjadi kesempatan bagi Malaysia memperbaiki dengan kualitas lebih baik kemudian dijual lagi kepada pihak lain. Menurut Camat J agoi Babang. sudah menjadi rahasia umum kalau kerajinan bidai yang masuk ke Malaysia itu sudah berubah dan mereka jual kembali. Dan menurut dia, bahwa masyarakat sebenarnya telah meminta kepada

16 Biday merupakan kerajinan tangan terbuat dari rotan, yang hasilnya berupa tikar, tas, dan lain sebagainya.

17 Wawancara dengan Bupati Bengkayang Suryadman Gidot, pada 24 Juli 2010 di Kantor Bupati Bengkayang.
Dinas Perindustrian dan Perdagangan setempat agar melakukan koordinasi dengan Dinas Perindustrian dan Perdagangan Provinsi Kalbar terkait masalah ini.

Belum adanya perlindungan hukum terhadap barang hasil karya penduduk asli seperti biday, permasalahan hukum yang sering terjadi di pasar perbatasan adalah penyelundupan yang sudah bersifat "transborders crimes" atau "transnational crimes", seperti illegal logging serta berbagai komoditi lain seperti rokok, batik, satwa/fauna (anggrek alam) yang dilindungi. Karena nilai jualnya yang sangat tinggi menjadikan barang atau komoditi ini menjadi salah satu barang yang diperjual belikan secara illegal di pasar yang ada di daerah Perbatasan kedua negara tersebut.

Barang-barang tersebut adalah barangbarang yang mudah dan laku dijual di daerah Malaysia, bahkan dilihat dari sisi ekonomi lebih menguntungkan jika dijual ke pasar dalam negeri. Hal ini dikarenakan nilai tukar dan nilai mata uang Malaysia (ringgit) lebih tinggi jika dibandingkan dengan mata uang rupiah. ${ }^{19}$

Masyarakat tidak pernah menyadari bahwa aktivitas tersebut merupakan perbuatan yang dilarang menurut hukum negara, sehingga pola penyelesaiannya yang dilakukan oleh masyarakat - jika terjadi persoalan diantara mereka - adalah dengan menyelesaikan secara damai antara kedua belah pihak karena dinilai lebih efektif. Pada hal persoalan tersebut muncul antara dua subyek hukum yang berbeda, baik tempat domisilinya maupun sistem hukumnya, sehingga pluralitas hukum yang melingkupi aktivitas perdagangan di perbatasan tidak hanya memperlihatkan aspek hukum lokal semata, tetapi juga sudah menyentuh aspek hukum nasional bahkan aspek hukum internasional. ${ }^{20}$

9 Wawancara dengan Ketua LSM LIRA Kabupaten Sintang.

20 Masaji Chiba, "The Intermediate Variable Of Legal Concepts", J ournal Of Legal Pluralism 1998 - nr. 41, hlm. 131; Martha-Marie Kleinhans \& Roderick A. Macdonald, "What is a Critical Legal Pluralism", Canadian Journal of Law and Society, Vol. 2 No. 2 1997; John Griffiths, "What is Legal Pluralism", J ournal of Legal Pluralism and Unofficail Law, No. 24, 1986; dan Sally Engle Merry, "Legal Pluralism", Law and Society Review, Vol. 22, 1988. 
Seperti diketahui bahwa pasar yang ada di daerah perbatasan merupakan tempat bertemunya berbagai macam kalangan yang memiliki perbedaan budaya, keyakinan, agama bahkan perbedaan asal negara. Dan basis sosial hukum selalu terkorelasi dengan budaya, keyakinan, agama dan bahkan ideologi, sehingga menjadikan hukum yang ada juga berbeda. Sehingga dalam perspektif pluralisme hukum, adanya berbagai macam sistem hukum yang ada di Pasar, seperti sistem hukum Masyarakat Lokal (Masyarakat dayak), sistem hukum Nasional masing-masing negara (Indonesia dan Malaysia Utara), serta berlakunya ketentuan hukum Internasional.

Masyarakat dayak Iban yang ada di Pasar Perbatasan misalnya, keberadaan hukum adat mereka masih tetap dipanuti dan tetap menjadi pedoman utama mereka dalam melakukan interaksi di pasar, karena hukum adat mereka (Masyarakat Dayak Iban) sulit hilang dalam ranah kehidupan mereka meski upaya menghilangkannya telah dilakukan dengan memperkuat keberadaan hukum nasional di tengah kehidupan sosial mereka. ${ }^{21}$ Demikian juga halnya dengan para pembeli yang berasal dari Negara Malaysia, dalam melakukan aktivitas di Pasar mereka masih tetap berpegang teguh kepada tradisi hukum mereka, yang umumnya berbasiskan pada hukum islam, pada hal hukum internasional sendiri telah meletakkan norma universal berkenaan dengan kehidupan negara yang bertetangga.

21 Dari penelitian yang dilakukan oleh Gordon dan Meggitt (1985); Moore (1986); Ottley dan Zorn (1983), memperlihatkan bahwa eksistensi hukum lokal atau hukum adat tidaklah hilang dengan begitu saja seiring dengan menguatnya hukum nasional suatu Negara bahkan dengan di jajah sekalipun. Lebih jauh lihat J ennifer Corrin Care and Jean G. Zorn; "Legislating Pluralism Statutory 'Developments' In Melanesian Customary Law", dalam Journal Of Legal Pluralism, No. 46, 2001, hlm. 51; F. von Benda-Beckmann, "From the Law of Primitive Man to Socio-Legal Study of Complex Societies", Antropologi Indonesia, Majalah Antropologi Sosial dan Budaya No. 47 Tahun XIII, 1989, Jakarta: FISIP UI. Lihat dan bandingkan dengan Sunaryati Hartono, "Kebijakan Pembangunan Hukum Menuju Sistem Hukum Nasional", J urnal Analisis CSIS, 1993-1; dan I Nyoman Nurjaya, "Pluralisme Hukum Sebagai Instrumen Integrasi Kehidupan Berbangsa dan Bernegara", Majalah Forum Keadilan, No. 51, 30 April 2006
Tidak jarang persoalan, seperti menjual secara bebas barang-barang hasil karya masyarakat setempat atau hasil alam yang seharusnya dilindungi oleh dokumen negara, yang ada di pasar daerah perbatasan tak terselesaikan dengan baik lantaran adanya perbedaan persepsi tentang keberadaan hukum yang ada di Pasar tersebut. Masyarakat Dayak misalnya, Biday dipahami oleh mereka sebagai bentuk karya yang tidak perlu mendapatkan perlindungan hukum sebagai Hak Kekayaan Intelektual dari negara, karena itu merupakan tradisi yang sudah lama ada pada masyarakat yang bersangkutan, miskipun menurut Hukum Negara perlu mendapatkan perlindungan hukum.

Demikian juga perkawanian yang terjadi antara penduduk yang berasal dari Kalimantan Barat dengan penduduk yang berasal dari Kuching (Malaysia Utara) tidak pernah atau jarang dilakukan dengan mendasarkan pada ketentuan hukum yang berlaku, baik hukum yang berlaku menurut hukum negara Indonesia ataupun Malaysia. Persoalan ini sesungguhnya tidaklah sederhana, sebab menyangkut keberadaan dua warga negara yang tunduk pada hukum yang berbeda, serta akan menimbulkan persoalan hukum - terutama persoalan hukum kewarganegaraa - terhadap anak-anak mereka kelak di kemudian hari.

Persoalan inilah yang dirasakan kurang diperhatikan oleh Pemerintah/negara dalam upayanya melakukan penataan terhadap pasarpasar yang ada di Perbatasan antara Propinsi Kalimantan Barat (Negara Indonesia) dengan Negara Malaysia Utara. Upaya penataan pasar yang dituangkan dalam penataan hukum masih terfokus kepada bagaimana memperkuat keberadaan hukum negara (Indonesia) dengan tetap memperhatikan ketentuan-Ketentuan hukum internasional pada suatu negara yang berbatasan langsung dengan negara lain. Sebagai contoh Pemerintah Indonesia sudah mengesahkan Undang-undang No. 43 Tahun 2008 tentang Wilayah Negara dan Peraturan Presiden (Perpu) No. 12 Tahun 2010 tentang Badan Nasional Pengelola Perbatasan (BNPP), penerbitan Undang-Undang tersebut merupakan salah satu bentuk keseriusan pemerintah dalam me- 
nangani persoalan-persoalan di kawasan perbatasan Negara. Namun yang perlu digaris bawahi bahwa keberadaan hukum adat (hukum lokal) yang ada pada masyarakat di sepanjang perbatasan masih belum mendapatkan perhatian dalam kedua aturan tersebut

\section{Penutup}

\section{Simpulan}

Berdasarkan permasalahan dan hasil penelitian, penulis menyimpulkan, pertama, berdirinya pasar di perbatasan pada dasarnya tidak diketahui secara pasti kapan mulai ada, tetapi dari keterangan penduduk sekitar, bahwa pasar di daerah perbatasan tersebut ramainya diperkirakan sejak 1900-an. Kedua, pola penyelesaian yang diambil oleh masyarakat, jika terjadi persoalan atau sengketa dagang antara pedagang dan pembeli, lebih menekankan pada proses damai, dan menghindari penyelesaian melalui badan atau lembaga formal seperti pengadilan ataupun Kepolisian. Hal ini terjadi karena ada kekhawatiran dari masyarakat jika hal ini dilaporkan ke lembaga formal maka bukan menyelesaikan persoalan, tetapi justru menimbulkan permasalahan baru, seperti hilangnya pelanggan mereka.

\section{Saran}

Berdasarkan uraian di atas, ada beberapa rekomendasi yang peneliti ajukan, diantaranya adalah diperlukan adanya penelitian lanjutan yang berkenaan dengan mekanisme penyelesaian, baik yang berasal dari sistem hukum masyarakat setempat, penyelesaian hukum menurut sistem hukum negara Serawak sebagai negara bagian Malaysia, serta sistem penyelesaian menurut hukum Indonesia, agar diperoleh bentuk perlindungan hukum yang mendasarkan pada prinsip-prinsip hukum internasional, Nasional serta tetap memperhatikan tatanan hukum yang berlaku dalam masyarakat (lokal).

\section{Daftar Pustaka}

Abubakar, Mustafa. 2006. Menata Pulau-pulau Kecil Perbatasan: Belajar dari Kasus Sipadan, Ligitan dan Sebatik. Jakarta: Penerbit Buku Kompas;
Benda, F. Von and Beckmann. "From the Law of Primitive Man to Socio-Legal Study of Complex Societies". Antropologi Indonesia. Majalah Antropologi Sosial dan Budaya No. 47 Tahun XIII. 1989. Jakarta: FISIP Ul;

Budhisantoso, S. "Pembinaan dan Pengembangan Kebudayaan Nasional", J urnal Kebudayaan No. 4 Tahun II 1992/ 1993, Jakarta: Departemen Pendidikan dan Kebudayaan;

Budiyati, Sri. "Pasar Tradisional dengan Struktur Bangunan Bertingkat: Siapa yang Diuntungkan", Newsletter SMERU. Lembaga Penelitian SMERU No. 22. April-J uni 2007;

"Quo Vadis Pasar Tradisional". Newsletter SMERU. Lembaga Penelitian SMERU. No. 22. April-J uni 2007;

Care, Jennifer Corrin and Jean G. Zorn; "Legislating Pluralism Statutory Developments In Melanesian Customary Law". Journal of Legal Pluralism. No. 46. Tahun 2001;

Chiba, Masaji. "The Intermediate Variable of Legal Concepts", Journal Of Legal Pluralism. No. 41. Year 1998;

Erlyn. "Legal Constructivism: Paradigma Baru Pendidikan Dalam Rangka Pembangunan Masyarakat Madani", Majalah IImiah Masalah-Masalah Hukum, Vol. XXX, No. 3, J uli - September 2001;

Firdaus, M. "The Integrated Empowerment of Women, Micro and Small Scale Traders", Newsletter SMERU. No. 22. April-J uni 2007. Lembaga Penelitian SMERU;

Galanter, Marc. "Why the "Haves" Come Out Ahead: Speculations on the Limits of Legal Change", Law and Society Review Vol. 9. Year 1974;

Griffiths, John. "What is Legal Pluralism". J ournal of Legal Pluralism and Unofficail Law. No. 24. Year 1986;

Hartono, Sunaryati. "Kebijakan Pembangunan Hukum Menuju Sistem Hukum Nasional", J urnal Analisis CSIS, 1993-1;

Hutomo, Suripan Sadi. "Nilai Budaya Indonesia Dalam Sastra J awa", J urnal Kebudayaan No. 2, 1991/ 1992, Jakarta: Departemen Pendikan dan Kebudayaan;

Koentjaraningrat. 1971. Manusia dan Kebudayaan di Indonesia. Jakarta: Penerbit Djambatan; 
Majid, M. Dien. 1988. Pasar Angkup (Studi Kasus Perilaku Pasar). J akarta: PT. Pustaka Grafika Kita;

Martha, Marie Kleinhans \& Roderick A. Macdonald. "What is a Critical Legal Pluralism", Canadian J ournal of Law and Society. Vol. 2 No. 2. Year 1997;

Merrit. "On Questions Following Questions". Language in Society 5. 1978;

Merry, Sally Engle. "Legal Pluralism". Law and Society Review. Vol. 22. Year 1988;

Nastiti, Titi Surti. 2003. Pasar di Jawa Masa Mataram Kuna Abad VIII-IX Masehi. Jakarta: PT. Dunia Pustaka Jaya;

Nugroho, Ganjar. Dominasi-Habitasi Pasar Dan Integrasi-Resistensi Structural Wong $\mathrm{Ci}$ lik, Makalah Workshop Asian Studying Cultural in Asian Context, Kunci Cultural Studies Center di Yogyakarta tanggal 1617 Mei 2002;

Nurjaya, I Nyoman. "Pluralisme Hukum Sebagai Instrumen Integrasi Kehidupan Berbangsa dan Bernegara". Majalah Forum Keadilan. No. 51. 30 April 2006;

Partigo, Poltak. (ed). 2004. Batas-batas Wilayah dan Situasi Perbatasan di Indonesia: Ancaman terhadap Integritas Teritorial. J akarta: Tiga Putra Utama;

Plattner. "Economic Decision Making in a Public Market-place". American Ethnologist 9. Year 1982;

Poesoro, Adri. "Pasar Tradisional Di Era Persaingan Global". Newsletter SMERU No. 22. April-J uni 2007. Lembaga Penelitian SMERU:

Polonyi, Karl. et.al. (ed). 1971. Trade and Market in The Early Empires: Economics in
Theory And History, Chicago: Henry Regnery Company;

Prattis, J I. "Synthesis, or a New Problematic in Economic Anthropology", Journal of Theory and Society. Vol. 11. Year 1982;

Sandin, B. "The Westward Migration of the Sea Dayaks", The Sarawak Museum Journal Vol. 7. Year 1956. Kuching: Museum Sarawak;

Stoler, A. "Garden Use and Hosehold Economy in Rural Java". Bulletin of Indonesian Economic Studies Vol. 14 No. 2. Tahun 1981;

Sumintarsih. 2007. "Perilaku Ekonomi Penduduk di Daerah Perbatasan Pacitan - Wonogiri". Jurnal Patrawidya, Vol. 8 No. 3. September 2007;

Suparlan, Parsudi. "Paradigma Naturalistik dalam Penelitian Pendidikan: Pendekatan Kualitatif dan Penggunaannya", Majalah Antropologi Indonesia No. 53, Vol. 21 1997. J akarta: FISIP UI J akarta;

Sutjipto, FA. "Beberapa Tjatatan Singkat Tentang Pasar-Pasar Di Djawa Tengah (Abad 17-18)". Buletin Fakultas Sastra dan Kebudayaan. No. 3. 1970;

Wilson. "Adaptation to Uncertainty and Small Number Exchange: The New Sugland Fish Market". J ournal of Economic. Vol. 11. Year 1980;

Swasono, Sri Edi. "Kebudayaan dan Ekonomi: Kedaulatan Rakyat, Demokrasi Ekonomi dan Kepentingan Nasional (Pendekatan Normatif)". J urnal Kebudayaan. No. 4 Tahun II. Tahun 1992/ 1993;

Yusriadi, Chong Sin dan Dedy Ari Aspar (ed). 2007. Kelompok Ibanik di Kalimantan Barat. Pontianak: STAIN Pontianak Press; 